\title{
Disciplinary Procedures for Judges: A Case Study of the Independence of the Jordanian Judiciary Law
}

\author{
Momen Nayef Ahmed Al-Sa'aida, PhD \\ Mohammad Abdul Muhsin bin Tareef, PhD \\ Mohannad Azmi Abo-Moghli, PhD \\ Amman Arab University, Faculty of Law, Jordan
}

\begin{abstract}
This paper focuses on highlighting the importance of judges' disciplinary procedures in the light of the law of the independence of the Jordanian judiciary as the supreme organ of the state. It also shows the role of the judiciary in adjudicating disputes between individuals or between individuals and the State in terms of its autonomy, independence of judicial supervision, and judicial immunity, as well as the disciplinary procedures. The following was discussed: concept of discipline and the adequacy of the disciplinary decision, the nature of the mistakes of judicial discipline, or disciplinary sanctions. The discipline of the public servant focuses on preserving the public right, respecting the reputation of public utilities, and building functional behavior that perpetuates the work of these facilities. The aim of disciplining judges is to focus on the administration of justice. The integrity of Judges makes the State a state of law. Through this way, the judicial process and disciplinary sanctions against those who violate the right and justice of judges do not in any way interfere with the independence and prestige of the judiciary in the society. It is stated that the existence of the same penalty in the law of the independence of the judiciary and in the Jordanian civil service system does not affect the essence of the independence of the judiciary. The penalty in its name shows one, but the implementation and importance in the law of the independence of the judiciary is different from that in the civil service system.
\end{abstract}

Keywords: Disciplinary Procedures, Judges, Jordan

\section{Introduction}

The principle of separation of powers has achieved a great leap in the history of legal thought. A number of Western jurists of the eighteenth century including Montesquieu in his book, The Spirit of Laws, are aware of this 
principle.This was followed by the Italian world of Piccaria.Western legislation and most countries in the world took this principle.

The idea of separation of powers has many consequences including the independence of the judiciary in the interpretation and application of laws. The evolution of the concept of judicial independence to ensure that the executive branch is not involved, and the independence of the judiciary, will make justice closer to verification. This will also reduce influence by individual tendencies and social relations that may distort justice.

The independence of the judiciary has many forms of verification which includes the non-interference of any of the executive authorities in the work of the judiciary, or in the work of any judge. This image has a presence in the Islamic heritage, and the rulers did not intervene in the work of the judges.

The provisions of Articles 98 and 100 of the Constitution stipulate that the appointment and dismissal of the regular judges shall be by royal will according to the provisions of the laws. The appointment of the types, grades, sections, terms of reference, and management of courts shall be in accordance with the provisions of their respective laws. The constitutional provision is consistent with Article 63 of the Civil Service Act No. 23 of 1966 issued under Article 120 of the Constitution, which stipulates that the appointment and disciplinary action of judges shall be in accordance with the provisions of their legislation (Shatanaoui, 2009, p.44).

The modern state works to achieve justice, equality, and freedom for its citizens as well as the distribution of the functions of its three powers, namely; integrative distribution. Thus, the independence of the judiciary - despite its importance and necessity - is relatively independent of the executive and legislative branches. It is independent of them, not separate from them. The division of duties between them makes the modern State a state of law and institutions.

\section{Problem of the Study}

Although the independence of the judiciary is functionally independent, a problem has risen in understanding the reality of this independence. It may imply that there is no correlation between the judiciary and the other two authorities, even in administrative procedures. This understanding is contrary to the principle of the modern state. The independence of the legislative and judicial branches does not mean that they are completely separated from one another. Rather, it means that these powers perform functions that the executive branch should, and should not, intervene in.

If we stop at the judicial authority, the legislation grants this authority privileges and competences. This is because the laws are applied by the legislative authority. Legislation between the authors is the executive 
authority, and the source is the legislative authority, which is applied by the judicial authority and the executors of what is issued by the judiciary. The provisions of this law are the executive branch, and the pivotal work in this is the judiciary. This is the reference on which the nation is based and the opponents return to it. The state is responsible for the separation of the disputes to which the state is a party. The state also protects the rights of the judiciary and assesses its provisions. In the interpretation of the laws, in contrast, the state pays salaries to members of the judiciary.

The different functions of the judiciary from the functions of the other two authorities should be based on a balance that preserves the authority of each of its functional entities. This study dealt with part of this balance, namely; the procedures for disciplining judges in light of the independence of the Jordanian judiciary.

\section{Purpose of the Study}

This study aims to answer the following questions:

Question 1: What are the objectives of the disciplinary measures of the public official?

Question 2: What are the objectives of judges' disciplinary procedures?

Question 3: What are the disciplinary procedures followed by the judiciary in dealing with irregularities in which some judges may fail?

Question 4: Are disciplinary measures taken by the judiciary in dealing with errors in which some judges are in violation of the principle of independence of the judiciary, which includes some of these procedures of the civil service system?

Question 5: If, in some of these actions, there is no objection to the principle of the independence of the judiciary, what can be proposed to eliminate this contradiction?

\section{Importance of the Study}

The importance of this study is to address an issue related to the principle of independence of the Jordanian judiciary. This involves the disciplinary procedures followed by the Jordanian judiciary in dealing with the mistakes of some judges.

The existence of judicial procedures to deal with this issue confirms the independence of the Jordanian judiciary. However, the adoption of the elimination of some procedures in the civil service law - if proven - does not prevent the Jordanian judiciary from being independent. In both cases, this does not create a conflict between the Jordanian judiciary independence. The conclusion of this study gives it special importance in legal research. 


\section{Study Hypotheses}

This study assumes the following:

First Hypothesis: If there is a contradiction between the procedures followed in disciplining the judges and the principle of the independence of the Jordanian judiciary, it is ostensibly opposed to a non-principled jurisdiction. This is ultimately an administrative procedure that does not affect the essence of the independence of the judiciary.

Second Hypothesis: If there is a conflict and it was initially assumed that it is possible to find a perception that removes this conflict.

\section{Study Approach}

This study follows the analytical descriptive approach. It is descriptive because it is a method based on showing the existing image of the independence of the Jordanian judiciary. In addition, it is analytical because it is based on addressing the vocabulary of the phenomenon and linking the parts and the characteristics of each individual. One of the features of the analytical approach is that it deals with the delicate issues and connects them to each other. Nevertheless, their resources diverge, separate them, and even appear to converge.

\section{The Limits of the Study}

This paper focuses on the Hashemite Kingdom of Jordan using the Jordanian Judicial Independence Law No. 29 for the year 2014, its amendments, and the Jordanian Civil Service Law No. 82 of 2013.

\section{Conceptual Framework}

\subsection{The Independence of the Jordanian Judiciary}

The independence of the Jordanian judiciary has many facets including what is related to its own characteristics, what is constitutional, and what is legal. Each of these characteristics presented are related to the main subject of this research. This is explained in three demands:

\subsection{Independence by Its Own Characteristics}

The administrative judiciary - as an arm of the judicial authority - is characterized by its own characteristics. For example, it has a modern origin in relation to civil law and constitutional law. Civil law is old, and many of its rules have been settled in the time of the Roman Empire, until their philosopher, Cicero, said: "We created to teach people the civil law". Some of the rules of constitutional law are known during the days of the Greek philosopher Aristotle. From the Greeks, people have defined the principle: "the people are the source of authority; administrative law is new, and the 
administrative law is still relatively limited to the subjects it should contain" (Sarayra, 2014, p.28).

However, the modernization of laws that change or adjust according to the requirements of social, political, and intellectual development in society does not stop.

One of the self-characteristics of the administrative judiciary is that it is rapidly evolving to keep up with the civilized development we live in, the resulting developments in administrative work, as well as the need to adapt to these innovations and resolve conflicts in the law. This requires that the review of the laws should be a continuous list. The existence of an independent system of the Judicial Council may be one of the most important requirements of its independence. However, its appeal to the civil service or work does not preclude it from the independence granted by the Constitution to the judiciary.

Nevertheless, the existence of legislation specific to all judicial affairs - including accountability and disciplinary measures - has demonstrated this independence. On the other hand, its absence - a first disagreement - does not necessarily mean that something of importance has affected the essence of the independence of the judiciary.

\subsection{Independence of Judicial Supervision}

Article 6 of the Jordanian Judicial Independence Law states that the Judicial Council "shall take over all matters relating to the regular judges including consideration, appointment, promotion, discipline, transfer, assignment, and termination of the judiciary in accordance with the provisions of this law". The Judicial Council oversees the judges' careers, monitors their performance, investigates justice and honesty, and makes judgments. In addition to their other functional matters, there is a practical translation of the independence of the Jordanian judiciary.

Article 6 of the Judicial Independence Law states that the Judicial Council has many functions, including "disciplining" judges, in the event that some of them commit irregularities. The significance of the article is clear in the sense that disciplining the judges is one of the proceedings of the Judicial Council, and not of any other authority in the State. However, does it necessarily imply that the law applied in this matter must be specific to the judges and not to others? The answer is that if the subject of disciplining the judges is to be exclusively for the judges, without other State officials, they should have special legislation system as example. If the use of disciplinary measures in the civil service system does not affect the essence of the independence of the judiciary, we can see this as a first disagreement with such disciplinary measures. However, we do not see the substance of the judicial system. 
The Council has been entrusted with many other tasks including article 23. They were appointed by the Secretary-General of the Ministry of Justice at the request of the Minister of Justice and a decision of the Judicial Council. The Council is the decision-maker, not the Minister of Justice. The executive authority follows the same principle when preparing draft laws and then sends them to the House of Representatives for discussion, approval, amendment or rejection of the final decision in this regard to the National Assembly with its wings: Deputies and dignitaries. This indicates two interrelated matters and the synergy of the three powers of the state: executive, legislative, and the immunity of the judiciary.

Article 18 of the Law on the Independence of the Judiciary states that judges are promoted from a higher degree on the basis of merit and competence derived from the Board's assessment. This is in accordance with the reports of the inspectors reported on the basis of their work.

Thus, the independence of the judiciary places on the Judicial Council many responsibilities, which are related to each other and are interrelated with the question of accountability of judges. The Council's supervision of the judges' performance is linked to accountability and discipline at the same time in terms of judicial performance, in dealing with colleagues and staff, or in any behavioral aspect. It is not only a precautionary motive, but it is an administrative duty required by the interests of the judicial system. Second, they are very careful not to fall into error. This is because this error has many things, including the negative effect on promotion from degree to degree Above all, the judge - in the final analysis - is a human being and someone can be caught in some irregularities.

According to the Law on the Independence of the Judiciary, the appointment of the Attorney-General is the prerogative of the Minister of Justice. This is not considered an interference in the judiciary. The prosecution represents the government, which demands the public right to protect and defend it. Here, the judicial authority is in synergy with the executive branch, and the executive branch works in this matter under the jurisdiction of the judiciary. The interdependence of the authorities does not mean the lack of independence of the judiciary and legislation. Also, it is more important to close the practical gaps between the three authorities.

Article 22 of the Law on the Independence of the Judiciary provides that judges are transferred from one post to another within the judiciary based on the decision of the Council. The President of the Council may appoint in the case of necessity any judge to any regular or special court. Alternatively, it is done to assume one of the functions of the Public Prosecution. The decision is to supervise the judiciary and not the Ministry of Justice, not the Council of its members, nor the judges who serve under the umbrella of the Judicial Council of the Ministry of Justice, except from the administrative 
authority only. On the other hand, the other ministers are responsible for the areas entrusted to them in the law. They are responsible for the employees of their ministries and the councils in which their ministries belong to them. As the case in the Council of Education, which is headed by the Minister of Education (the Ministry of Education), the Council of Ministers is independent of the Ministry of Justice. An exceptional case is in what the Council requires from the executive branch for the duration of its work, which is also relevant to the independence of the judiciary.

\subsection{Judicial Immunity}

Immunity is the denial of accountability, and the constitutions of many States have granted the judiciary the immunity to enable it to achieve independence. This immunity is therefore the guarantee of this independence, which is an evidence of its existence. The immunity does not mean that the offenses committed by the judiciary are not subject to accountability. The judicial immunity is the one that preserves this authority and assigns it to the administration of justice and the resolution of disputes between the litigants. Nevertheless, it also means that the Judicial Council represents the judiciary, which judges for any irregularities that may arise from them. Everyone is under the rule of law and no one is above this authority. There is no contradiction between the fact that the judiciary is an independent authority and immunity that is integrated with the law and does not contradict it. Immunity is therefore not free of charge. Otherwise, immunity would not have functioned but had been breached. As a result, the judges would have been held accountable for the irregularities that might result from a translation of the immunity function itself.

\section{Objectives of Disciplinary Sanctions}

Since the punishment is not an end in itself, it therefore aims at other things, including the preservation of the society as a whole from crime. This is despite the fact that the laws differ from one another in objectives, nature, and field. Also, they all meet some of the general objectives of preserving society and the establishment of justice among its children. Therefore, these are the objectives for which the administrative irregularities were established:

1. The reform of those who are in violation and the penalty when applied to those who are in the administrative irregularities serves as a warning punishment to the other employees. This is consistent with the fact that the administrative sanctions - and others without doubt - deterred from the occurrence of administrative facilities in the administrative chaos. The discipline states that Dr. Noufan Ajrama "aims to detect flaws in the administrative construction, a 
prelude to its reform in order to prevent the commission of administrative irregularities in the future" (Ajarmeh, 2007, p.65).

The objective is to improve performance. It improves its performance, but it becomes a practical behavior in his life.

Therefore, this achieves two goals: one of which is positive in terms of mastering the work of the job as required by law, while the other is negative due to the occurrence of administrative irregularities.

The opinion of the researcher on the perception of repairing who is in error in the public utilities ultimately lead to the correctness of public facilities and integrity. This would help to achieve the objectives of these facilities, as will be explained in the next paragraph.

2. Preservation of public facilities and the safety of their performance to achieve their objectives: Dr. Noufan Ajrama believed that "when the public employee understands that any negligence on his part, or negligence in the performance of his duties, will be faced by the administration disciplinary penalties ... This is an incentive for the employee to attend regularly. "The punishment is not an end in itself, but rather a means for the public utility to carry out its mission." (Ajarmeh, 2007, p.65)

This does not mean the administration of justice at the expense of reassurance, but it only means that reassurance is rooted in the behavior that surrounds itself with great caution, which harms this tranquility.

The opinion of the researcher shows that this goal is another picture of the administrative irregularities exceeded by administrative officials. Thus, this leads the rest of the staff to commit violations. So, they were frequent violations until the facilities deviate from what they were meant for. The commission of the offense shall be without prior accountability by the staff and fall into the offenses which they believe may be committed without any disciplinary action being taken.

In the area of the judiciary, judges are role models in the application of the law, and their commitment to it makes all workers in the judiciary not to be careful to fall into irregularities and be held accountable. Also, people trust the performance of the judiciary and the integrity of the goal which ultimately leads to the integrity of work.

The concept of the independence of the judiciary does not indicate its separation from society and the state, nor does it indicate that it 
is exempted from complying with laws, regulations, and instructions.

1. Achieving Justice and Equality: The disciplinary penalties that should be committed by the administrative staff and the judges, in the first instance, serve to show the bright image of justice and equality. The judge's obligation to treat everyone on the same basis of equality and adherence to the law promotes justice and equality in the judiciary. If not, the judge has committed a legal offense that deserves to be held accountable. This is same for everyone in front Law and before justice either.

2. Forming a Professional Ethical Behavioral Pattern: Ethical professional conduct is one of the main factors in forming a system of clear and lawful dealing. This obligation remains a companion in one's life. This is because it takes an ethical character that is embarrassed from making a mistake. Disciplinary punishment is also given to whoever makes a mistake, regardless of his or her position. More so, wherever he or she is located, staying committed to professional ethical conduct is easy.

3. There is a big difference between the world of perfection and the world of idealism. Exonerating the judiciary of wrongdoing makes the judiciary an ideal image in society. This means that, at the same time, it is a form of preserving perfection and the application of ideal in the real world.

\section{Mistakes of Judicial Discipline}

A mistake that calls for judicial discipline is any act or omission of an act required by law, which undermines confidence in the duties of the judicial function or damages the reputation of the public facility. These are of two types: a minor error that does not prejudice the duties of the job, and it does not undermine confidence in the judiciary. The second error, which is the serious mistake that the observer generates, is a legitimate conviction that the judge is unable to perform his or her function impartially and independently. These include, but are not limited to:

1. Absence of work before obtaining written approval. Article $16 / \mathrm{C}$ of the Jordanian Judiciary Independence Law states that: The judge shall not be absent from his work before obtaining the approval of the official's representative and he shall not cease his work because of a surprise before the President shall allow him to do so in writing. The words "may not" indicate that if the judge does so, he shall be liable to disciplinary punishment because he has done what he is not permitted to do. 
In addition, the provisions of the preceding article are consistent with administrative practices in public facilities. However, the prior approval of some administrative practices in such facilities is often sufficient to be oral. The judiciary and other administrative facilities agree that work cannot be absent without prior authorization. They differ in the fact that the authorization must be in writing in the judiciary and may be oral in administrative practices in public facilities. This has been customary as opposed to what it should be. Administrative instructions have created a so-called "exit permit" to solve the defect in case of delay, departure, or absenteeism. However, the difference of justice with the administrative conduct in other public facilities in the State emphasizes the independence of the judiciary. Also, their agreement confirms the integration of goals and objectives between the judiciary and other administrative facilities.

2. Combining the function of the judiciary and the conduct of business or the membership of the board of directors of any other company, institution, authority, job or profession under the responsibility of the Minister of Justice as stipulated in paragraph (e) of Article 16 of the Jordanian Judicial Independence Law.

3. To perform any act that will benefit his relatives. Paragraph (f) of Article 16 of the Jordanian Judicial Independence Law stipulates that.

4. The judge shall accept the bribe or request from any party, whether directly or through another party.

5. The judge shall accept the gifts directly or indirectly, whether at his place of business in the court or any other place where such occurrence is proved.

6. The judge's acceptance or application for any services or interests directly or indirectly related to his work as a judge which is linked to a case in his hands, or related to a case in the hands of another judge.

7. Obtain a material wealth or a costly lifestyle without being able to prove a legitimate source of wealth.

8. The threat of using his position to harm anyone under any circumstances.

9. To carry out any act that would affect the course of litigation for the benefit of one party without another, which is directed towards him or any other judge.

10. To falsify the judgments issued by him or any other judge, whether alone or with any other party.

11. Establish social relations with any person subject to criminal prosecution in any offense constituting a felony or misdemeanor.

12. Refrain from making a judgment in a case for any reason, which is tantamount to the fact that this abstention is based on the excuse that 
justice is not achieved in that, or on the basis of his own thought and beliefs, or for any other reason not recognized by law. Accountability is required.

13. Delay in deciding the cases in his hands.

14. Favor any team of opponents to declare or hint.

\section{Disciplinary Proceedings}

This section includes four demands: the concept of discipline and disciplinary sanctions, judicial discipline in the light of the law of the independence of the judiciary, the transfer between punishment and administrative procedure, and the disciplinary procedures for judges.

\subsection{The Concept of Discipline}

It is important to distinguish between discipline and disciplinary offenses. Disciplinary offenses have been defined by some jurists as: "any conduct made by the worker during or outside the performance of the job which affects it in such a way as to prevent the facility from fully functioning" (Al-Tamawi, 2018, p.101).

Disciplinary offense was also defined as: "a person who belongs to a particular personality and has been violated by the duties of the law" (AlMajali, 2017, p.70). Disciplinary action is the punitive action taken by the judiciary against a person who commits an administrative offense, namely; the effect of the crime. It is mentioned because they all agreed to identify the crime and its elements.

The offense within the scope of the Penal Code has two main pillars:

4.1.1 The Physical Element: This is the unlawful behavior that proves the employee's occurrence, such as: breach of duties, violation of public behavior, and physical property. This is divided into two parts: positive and negative. Its main purpose is to bring the employee to the wrongful act, which is signed by the third party. The negative is the abstention from the legitimate act that signifies the employee's abstention from causing harm to others.

The proof of the physical element is fundamental to the occurrence of violations that are punishable by law. Therefore, this element is described as "the unlawful conduct in which the employee is found to be ..." A proof of wrongdoing and transgressions is extremely important in condemning the perpetrator and the sentence. It is not sufficient to doubt, but it is necessary to investigate.

4.1.2 The Moral Element: This has been defined by some as "the employee's illegitimate will, or a feeling of contact with an active will which led to the commission of the offending act." (Battarsa, 2017, p.188). This will is 
expressed as a sinful will. This is because it is the moral pillar that leads to the wrongful conduct.

However, it is the latter that appears to be visible or physically aware. The accountability of the sinful will can only be achieved through the behavior that has led to it. Through this behavior, the actor falls into the accountability of the law for this sinful will and these two pillars are the complete crime.

It is better to stand here when defining the moral element that has been discussed above, which states that the moral element is "... a feeling of contact with an active will that led to the commission of the offending act." It can be stated that the issue is not merely a feeling of active will.

Some jurists have pointed out that there is no requirement for the criminal will to impose disciplinary responsibility against the employee who has committed the act of punishment. Their argument, however, is that the violation has occurred and that this will "means nothing more than the fact that the employee committed the act or refrained from acting without a legitimate excuse. He is aware of the fact that he committed an erroneous act or not, improved his intention or worsened it, whether the offense was intentional or tortuous" (Al-Tamawi, 1991, p.84). This means that the offense took place whether the offender knew that he committed an offense or not, whether his intention was good or bad, or whether the violation was simply a failure to perform the job.

However, there is no doubt that this view is logical, whether it is true or exaggerated in the exclusion of the sinful will. It is considered in some administrative irregularities. At the same time, if it contradicts with the error in good faith, the will is not available in such a situation.

To make the point of view of these jurists more clearly, it is wrong to make a financial mistake when setting up a budget. This is because the budget is the balance that controls the financial behavior during the year (expenses, revenues). Every error is great, whether it is intended or unintended or done in good faith or bad faith.

Administrative law does not take the personal criterion that is based on a person's behavior in proving disciplinary responsibility, but rather on the objective criterion that is based on the normal behavior of the average person. Any deviation from this behavior is wrong, regardless of its degree.

\subsection{The Appropriateness of Disciplinary Decisions}

The principle of the appropriateness of disciplinary decisions is to take into account the disciplinary authority to suit the degree of the offense committed by the staff member. States shall ensure that administrative disciplinary decisions are commensurate with the extent of the administrative offense committed by the staff member. When jurists speak of the appropriateness of disciplinary decisions, it is appropriate for the position of 
the judicial system to consider its independence and to preserve its prestige, and to have special legislation that includes irregularities in which some judges may fail. In addition, there is a need to harmonize the situation of the judiciary with the mistakes of some of its members by enacting legislation stating the offenses committed with the determination of disciplinary penalties to be limited in the case of crimes. Also, the penalties should be specified in the Penal Code. In this study, the privacy of the judicial system has been taken into account which affirms its independence and preserves its prestige. It is also worthy to note that the civil service system is the source of some disciplinary measures. This indicates that the legislator avoids the existence of special legislation to avoid the sensitivity suggested by the principle. The most important thing which the independence of the judiciary suggests is that the body has all the relevant legislation, including legislation on disciplinary procedures. However, the absence of such legislation in the civil service system does not mean that the judiciary is not independent.

There is reason to emphasize that disciplinary sanctions used by the Judicial Council from the civil service system may be appropriate for workers in many State facilities. However, some may not be applicable to the judiciary. Also, when some disciplinary sanctions in the civil service system are not appropriate even in the other civil administrative organs of the State, amendments are repeated.

\subsection{Discipline between Administrative and Judicial Independence}

Discipline is the impact of the two corners of the crime: material and moral. It is the punitive effect that results from the violation of the law and the denial of the duties that the job is given to those who belong to it.

However, does the administrative law require that the perpetrator be punished by a pre-prepared legal provision, pursuant to the Code, which is not a crime or punishment without a text? The Criminal Code limited the offenses and decided each offense before its perpetrators committed a specific penalty. The laws and regulations of the job did not include a definition or a specific disciplinary offense, unlike the penal legislator, which adheres to the rule of no crime or penalty except by text. Administrative offenses are not confined to predefined texts, but rather to disciplinary authority. It is possible to limit the scope of administrative offenses by enactment of legislation, to prosecute them regularly, and to expedite the determination of penalties for them. It is possible that the Judicial Council, in cooperation with the executive authority, and other legal bodies such as the Bar Association and other legal facilities, will work on all possible crimes by forming specialized committees for this purpose.

At the end, it will be possible to narrow out the crimes that come out of the circle of enumeration. Also, if it comes out of something from the circle 
of inventory, it is possible to measure what arises from them. The crime is measured in the minds of criminals which is a psychological basis known in criminal behavior patterns. Finally, administrative crimes have been closed, although not completely limited. This supports the possibility of limiting the crimes when the legislator allows the Judicial Council to assess the appropriate penalties for crimes. However, such an estimate is not without the fact of measurement, development or circulation.

In the the civil service system, No. 55 for the year 2002 in Chapter 16 is a list of disciplinary penalties which the disciplinary authority may sign for the employee who commits a disciplinary offense.

4.4.1 The Alarm: It is - in terms of punishment - the administrativeguidance to the employee issued by the administrative authority, which includes the employee's reminder of his duties. If the punishment includes every administrative procedure that addresses the imbalance, the warning is punishable because it mentions a defect that does not satisfy the administration. The reminder in itself is indicative of a violation, and it is based on dissatisfaction with its existence.

The right, in our opinion, is that punishment does not entail a physical procedure but a psychological nature. Thus, our opinion on the matter is united between the two scenarios. Thus, the warning, even though is the lowest punishment, is an unwarranted warning which may result in a physical rhythm, especially if it is written in the judge's profile. This clearly indicates that the warning is a punishment and the employee sees the lowest degree of career alert as punishment. The error or default that was issued from him is similar to having a backup procedure. Therefore, the alert - especially if it repeats, and may recur - stands in the face of promotion from one degree to the next. If the alarm affects the promotion in civil facilities, it is also in the judicial field.

The alert, like all other sanctions, should be a written decision. However, some of the alerts can be oral when the level of the violation is not lawful.

4.4.2 The Warning: The act of authoritarian punishment is more severe than the warning. Here, the warning of the employee to fall again, in the violation of his work, falls within the circle of sanctions that is less serious. Also, it does not provide the Civil Service No. (55) for the year 2002 on how to stay alert. Although the previous regime amended it, there is no indication in the system of the number of warnings that can be inflicted on the employee. Hence, this does not only mean salary, but it also addresses the level of career and authority. 
4.4.3 The Deduction from Salary: This type of financial sanctions, which affects the financial position of the violator and the laws, differ in determining the amount of what is deducted from the salary. As a disciplinary measure, Jordanian law did not set a higher limit of the number of discount. Deduction shall not exceed two months in one year (Al Ajarmeh, 2007, p.65).

Consequently, we support the fact that some do not include sanctions of a financial nature in penalties in accordance with principle of personal punishment and justice. It is essential that sanctions of a financial nature should not be included in disciplinary sanctions list because the effect of such sanctions is not limited to the offender. Basically, this effect is extended to all members of family, and the entire salary is not enough for necessities of life. Therefore, it diminishes in the face of rising prices thereby making the discount worse (Al Ajarmeh, 2007, p.65).

4.4.4 Withholding the Annual Allowance: We propose that this penalty be replaced by the penalty of deduction from salary, provided that this does not affect the employee's solutions for that year. This year is one of the years of actual service that is calculated for him upon retirement and at the end of service benefits.

4.4.5 Reduction of the Premium in Whole or in Part: This punishment is a financial sanction related to the reduction or amount of the allowance, which is dependent on the magnitude of the offense committed by the violator.

4.4.6 Reduction of Salary: Article (153/1) of the Civil Service Law stipulates that the salary of the employee who has been subject to disciplinary punishment shall be reduced by not more than three years annually and shall not be considered in this case before the passage of a number of years which is covered by the penalty.

4.4.7 Reduction of the Degree: This is achieved by reducing the degree of the employee who occupies it to the degree immediately before it. This penalty is more severe than the financial penalties because it includes three penalties: lowering the employee's degree in the administrative ladder to the level immediately preceding it, lowering his salary to the degree to which he was punished, and not raising him three years before the disciplinary punishment against him.

4.4.8 Abandoning Service: This is one of the most severe penalties in administrative law.

4.4.9 Isolation: It is the most severe punishment. 


\subsection{Transfer between Punishment and Administrative Procedure}

Many public and private bodies and institutions have used disciplinary transport as a means of punishment. Transport is defined in two different directions, one as headquarters and the other as an authoritarian act. Some have defined it as "a change of place of work or place of residence imposed by the administration on the employee with its own will" (Qabilat, 2010). As an authoritative measure, it was defined as: "a discretionary authority of the competent administrative authority to enable it to make transfers between its staff in order to make the best use of the abilities, expertise and qualifications of the public official" (Qabilat, 2010, p.235).

In our view, transport can be defined as: "an authoritarian action taken by the administration to change the location of the employee in favor of the institution or employee or both, a career transfer, or a punishment that the administration expects of the staff, namely disciplinary transfer." The transfer of the employee from a job to a lower level or transfer from one area to another can harm the employee's employment in one way or the other. This is known as arbitrary transfer. In Civil Service Law No. 30 of 2007, "The staff member may not be transferred to a post of less than his or her original job, which has been upheld by the Court of Justice. It was stated on Article (63/C) of the Civil Service Law No. (1) for the year 1998 and settled jurisprudence that it is not permissible to transfer the employee to a degree less than the original degree.

\subsection{Discipline of Judges}

The mistake of the judge is much greater than the mistake made by the judge himself or his counterpart if he was not a judge. This means that the judge's mistake is wrong with the profession itself, which is a mistake concerning the rights of the people.

In our view, the measures taken to prevent the judges from making mistakes are the ongoing moves by the Judicial Council. These movements are not necessarily based on the wishes of the judges. On the other hand, they can take an umbrella that conceals an ordinary punishment of judges. Third, the judge is warned of what may be the reason for his transfer to an area where he may not be satisfied and that may be a remote area.

When comparing the contents of the Jordanian civil service system and the penalties stipulated in the law of the independence of the judiciary, we found a correlation between them as shown below:

\subsubsection{Article (15) paragraph (C) of the Independence of the Judiciary Act of 2014 states:}

"The council may, at the direction of the president based on the recommendation of the committee formed under paragraph (A) of this article, 
refer any judge who has served for at least twenty years to retirement, and to the pension if he has spent at least fifteen years of service or has terminated his service if he has not completed the period of service necessary for his transfer to retirement".

Accordingly, we found in this article a series of penalties for incompetence, which is determined by the Committee referred to in the same article. This is based on the judge's performance and recommendations:

1. To refer the incompetent judge to retirement if he has completed twenty years of service. This means that the assignment to retirement has become a disciplinary penalty, but we consider that this punishment is disproportionate to incompetence. This is because this status should not continue as the judge will be able to review the matter. Subsequently, if the judge has performed well throughout this period, then his performance will be reversed at the end. It is better not to remain silent due to poor performance no matter how short is the period.

2. The referral of a judge who does not prove his good performance in the case of a detention if he has completed fifteen years of service. Such action - a penalty - is disproportionate to poor performance.

3. Termination of the service of a judge who does not prove his good performance if he does not complete the period necessary to refer him to retirement.

\subsubsection{Article (15) paragraph (D) of the Judicial Independence Act No. 29 of 2014 stipulates:}

"The Council, upon the recommendation of the President, shall terminate the service of any judge who has not completed the period of retirement for incompetence only if his annual report for two consecutive years is less than good." This paragraph is a statement and an explanation of what is stated in paragraph $(\mathrm{C})$ of this article. The lack of good performance has been linked to the lack of good estimate for two consecutive years. In this matter, there are two aspects. The first aspect is that the judge's judgment is less than good. Within the first time that he received the assessment, there was no need to wait for an annual report that was less than good in two consecutive years. Secondly, the assessment should not be unique to the judicial inspectors, but it must be shared by the President of the court to which the judge belongs. This undermines the integrity and fairness of the inspector. Although the head of the court knows details that help the inspector, the performance of his work is either positive or negative. In any case, a judge whose performance is low should follow his work carefully and take measures that would improve his performance or disciplinary action. 
4.6.3 Article (25) paragraph (A) of the Judicial Independence Law No. 29 of 2014 states: "The judge may not be dismissed except by discipline and by a decision of the Council of Royal Decree."

Following this, this article decides three things:

1. The removal of the judge and the dismissal of his service are disciplinary punishments taken by the Judicial Council against those who are subject to serious mistakes by the judges, which require such punishment. The isolation and dismissal of the service of the judge depending on the penalties is adopted by the Jordanian civil service system.

2. The judge is immune from receiving one of the two penalties from the President of the Court or any other official.

3. The judge is immune to another encroachment so that he is not subject to dismissal or dispensing his services except by discipline. This means that the difference in opinions, beliefs, and political ideas adopted by the judge and his personal beliefs that do not affect his work and his good performance are not a way to harm him. This is a powerful proof not only for the judge, but for the judicial system and the judiciary as a whole. This is a practical demonstration of the independence of the judiciary. It is immune to the conflicts that are taking place where other people are located. Also, the work of the judge proves the validity his behavior.

4.6.4 Article (25) of the Judicial Independence Law states: "The degree of a judge may not be reduced except by a decision of the Council."

In view of the previous article, it contains two things:

1. The lowering of the judge's degree from the disciplinary penalties established by the Jordanian Judicial Independence Law.

2. This penalty is one of the jurisdictions of the Judicial Council and no one else has the right to punish it.

4.6.5 Article 27 states: "The President shall, on his own initiative, or on the recommendation of the First Inspector, or the President of the Court in charge, have the right to notify the judge in writing of everything that is committed, contrary to the duties or requirements of his job, and keep this alert in the file of the secret judge, taking into account all the safeguards of the defense.

The following is also found from this article:

1. The warning is one of the penalties stipulated in the Jordanian Judicial Independence Law, and it is also present in the Jordanian civil service system.

2. As a result of mitigating penalties, the President of the Judicial Council signs the penalty of his own motion, without referring to the Council, 
and may sign it on the recommendation of the President of the Court in which the judge is serving or on the recommendation of the First Inspector.

3. The fact that this punishment is mitigated has an effect on the judge's position. This is because it is based on a written examination by the President of the Council, and it takes into account the entire defense guarantees. If the warning was not considered a significant penalty, it would not have had such procedures which include: linear questioning, keeping the alarm in the secret file, and taking into account the safeguards of the defense. In the civil service system, it is important not to alert this effect to the status of the employee.

4.6.6 Article 28 (a) - 1 stipulates that: "In cases other than that of flagrante delicto, a judge may not be prosecuted or arrested without obtaining the permission of the Council."

This article contains the following:

1. In the event of a criminal offense, a judge may be prosecuted or arrested before obtaining a permit from the Council. Paragraph 2 of paragraph (a) indicates that in this case, the deputy must bring the matter to the Council within the next 24 hours.

2. In a case other than that of flagrante delicto, a criminal offense may not be prosecuted or arrested before obtaining the permission of the Council.

4.6.7 Article (33) of the Judicial Independence Law stipulates: "The disciplinary action shall end with the resignation of the judge, the acceptance of the council, or by his referral to retirement or retirement, and the claim shall not affect the criminal or civil action arising from the incident."

It is understood from this article as follows:

1. The resignation of the judge, his retirement, or suspension in these cases is a disciplinary sanction.

2. However, resignation or referral to retirement or retirement does not affect the criminal or civil action arising from the same incident.

\section{Previous Studies}

This study is based on three sets of sources:

1. Theoretical Jurisprudence on the Issue of the Independence of the Judiciary and Disciplinary Procedures from Books, which are Fundamental References to the Theoretical Aspect of this Study

The resources of this aspect of the literature on jurisprudence in this study are many. However, the study deals with them in a way that is different from what 
is found in these references, and this was mentioned in the list of sources and references.

\section{Procedures for Dealing with Errors of Judges}

The source of these procedures is the law of the independence of the judiciary. It is compared to the Jordanian civil service system because these procedures are taken from the system.

\section{Research and Studies Related to the Subject of the Study}

A number of studies were found that dealt with the subject in a number of Arab countries. These studies include:

(1) What was published by the site of the legal journal in the Internet in research papers on the reform of the judiciary in Lebanon including a research paper prepared by Nizar Saghieh, Maryam Muhanna, Joel Boutros, and Jassim Shaheen titled "Mechanisms of Discipline Judges"? The paper outlines the legal framework for judges' disciplinary mechanisms, disciplinary mechanisms in practice, and problematic issues. The paper was also accompanied by proposals including: the abolition of parallel disciplinary proceedings that do not meet the requirements of a fair trial, and the transfer of the judge to punish him (www.legal-agenda.com).

(2) The Study of Abdul Wahab bin Awad Al Harbi titled "Reprimanding the Judges in Islamic Law and the Saudi Regime: This is originally a letter submitted by the owner to complete the requirements for obtaining a master's degree at the Islamic University in Medina. It is clear from the title of the letter that this is based on a comparison between the reprimand of the judges in Islamic law and the Saudi judiciary.

(3) The Study of Sharif Balousha titled "Discipline of Judges in the Palestinian Judicial Authority Law of 2002": This is a study in which the owner dealt with the procedures for the trial and discipline of judges in the West Bank.

\section{Conclusion}

The judicial authority under the Jordanian Constitution of 1952 has its independence which guarantees justice and equality. This independence is a sign of the principle of separation of the three powers from one another. The judiciary is independent from the legislative powers and the implementation of the law on the independence of the judiciary in Jordan. This law focused on some aspects of the penalties contained in the Jordanian civil service system and was made in cases of errors and irregularities such as: deduction of salary, delay promotion, retirement or retired insulation. Furthermore, this has raised some questions from judges to this effect: Is it inconsistent with the independence of the judiciary law? The question is that this is an administrative issue that does not conflict with the independence of the 
judiciary. The laws may take some provisions from other legislations and from jurisprudence. This is because there is no harm in using the jurisprudence, and there is no objection to using some of the other legislations.

The concept of immunity enjoyed by the judicial system under the Constitution does not mean that those who fall into error are not held accountable by the judiciary. Therefore, the punishment was taken for granted as stipulated in the Law on the Independence of the Judiciary. The ultimate goal of punishment is to achieve justice and equality, to maintain the judiciary itself, and to preserve the security and safety of the society before any other consideration.

The Law on the Independence of the Judiciary contained errors in the punishment of some judges. The research discussed each of them separately. The research depended on the connection of the sentence to the issue of immunity of the judiciary. This is because immunity in its broad sense meant the immunity of the entire judicial system. Also, the concepts are not contradictory, but complementary. Consequently, the research compared discipline in the administrative judiciary with the law of the independence of the judiciary while invoking the concept of the independence of the judiciary. Ultimately, the independence of the judiciary, although it should be appropriate, does not prevent the law of the independence of the judiciary from taking what exists of penalties in the civil service system or other legislation.

\section{Results}

The results of any scientific research is related to accessing answers to the questions posed by the research. The course of the research also includes a practical examination of the hypotheses developed by the researcher. Hence, the answers to those questions are in fact the most important results of that research. Thus, these are the results of this research:

1. There are a number of penalties for one offense, such as: lowering the rank of the public employee. In this case, the penalty is reduced to the degree and the salary is reduced at one time.

2. The Law on the Independence of the Judiciary provides for the referral of an incompetent judge to retirement if he has completed a period of twenty years of service. This means that the referral to retirement has become a disciplinary penalty.

3. The Law on the Independence of the Judiciary and the Civil Service Law contains several penalties that apply to the violating employee. This includes the financial penalty which affects his financial position and results to deduction of salary.

4. There is no special section dealing with disciplinary sanctions that apply to the offending judge in the Jordanian Penal Code which should include the appropriate penalty for violation. 


\section{Recommendations}

The present study recommends the following:

1. The Jordanian legislator should make some amendments to some of the penalties that show the multiple penalties for one offense, such as: lowering the rank of the public employee. In this sentence, the penalty is lowered to the degree and the salary is reduced at the same time.

2. The Jordanian legislator will review the question of referring the judge to retirement after his term of service because of lack of efficiency. This should be done so that the status of the performance of the judge will not continue for a long period in silence until the completion of twenty years in service.

3. The Jordanian legislator should not impose the penalty of deduction from salary because it affects the employee and his family. This proposal includes deduction from the salary of the employee. However, in any legislation, in the law of independence of the judiciary or in the civil service system, this can be replaced with other penalties.

4. The Jordanian legislator should enact special legislation to deal with the disciplinary sanctions that apply to the offending judge. This should be added to the Jordanian Penal Code and include appropriate penalty for violation, while taking into account the graduality and suitability.

\section{References:}

1. Al Ajarmeh, N. (2007). Authority of Discipline of Public Employee. Amman, Cultural Library, p. 65.

2. Al-Anadli, M. (2018). Judicial control of proportionality in the administrative decision. Amman, Dar Wael.

3. Al-Majali, N.T. (2017). Explanation of the Penal Code - General Section, Sixth Edition. Amman, Cultural Library, p. 70.

4. Al-Tamawi, S. (2018). Administrative Control in the Administrative Decision. Amman, Wael Library, p. 101.

5. Al-Tamawi, S. (1991). Al-Wajeez in the administrative judiciary. Cairo, Dar al-Fikr al-Arabi, p. 84.

6. Baloush, S. (Without history). Discipline of judges in the Palestinian justice system for the year 2002, www.legal-agenda.com

7. Battarsa, S.S. (2017). General function - theory and practice. Amman Cultural Library), p. 188.

8. Harbi, A.W. (Without history). Discipline of judges in Islamic law and the Saudi regime, www.legal-agenda.com

9. Jordanian Civil Service Law No. (55) for the year 2002.

10. Jordanian Judiciary Independence Law No. (29) of 2014. 
11. Qabilat, H. (2010). Administrative Law, Part II, 2nd ed. Amman, Wael Library, p.235 - 293.

12. Saghieh, $\mathrm{N}$ et al. (Without history) Reform of the Judiciary in Lebanon, www.legal-agenda.com

13. Sarayra, M.M. (2014). Administrative Law, 2nd ed. Amman, Cultural Library, p. 28.

14. Shatanaoui, A. K. (2009). Administrative Law, First Book. Amman, Wael Library, p. 44. 